\title{
economics-of-security.eu
}

Teun van Dongen

\section{Break it Down: An Alternative Approach to Measuring Effectiveness in Counterterrorism}

December 2009

Economics of Security Working Paper 23

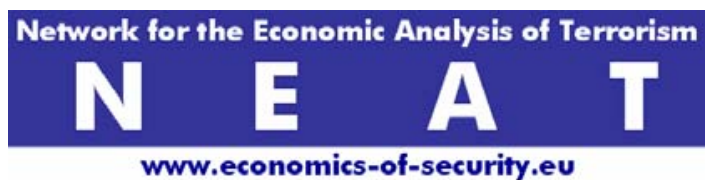




\section{Economics of Security Working Paper Series}

Correct citation: van Dongen, T. (2009). "Break it Down: An Alternative Approach to Measuring Effectiveness in Counterterrorism". Economics of Security Working Paper 23, Berlin: Economics of Security.

First published in 2009

(C) Teun van Dongen 2009

ISSN: 1868-0488

For further information, please contact:

Economics of Security, c/o Department of International Economics, German Institute for Economic Research (DIW Berlin), Mohrenstr. 58, 10117 Berlin, Germany.

Tel: +49 (0)30 $89789-277$

Email: neat@diw.de

Website: www.economics-of-security.eu 


\title{
BREAK IT DOWN
}

\section{An alternative approach to measuring effectiveness in counterterrorism}

\begin{abstract}
This paper will review the ways in which the effectiveness of counterterrorism measures and policies has been assessed and argue that they suffer largely from the same difficulties. For many of the chosen indicators it is not clear whether they represent what they are supposed to represent and whether shifts in the scores can be attributed to counterterrorism. After having discussed these problems, a different way of measuring counterterrorism effectiveness is outlined. It rests on the assumption that counterterrorism should be broken down into separate components that should all be evaluated separately. For all components, a causal chain from cause (measure) to effect (shift in indicator) should be formulated to solve the meaning and attribution problems.
\end{abstract}

Correspondence to:

T.W. van Dongen

The Hague Center for Strategic Studies

Lange Voorhout 16

2514EE The Hague

teunvandongen@hcss.nl 


\section{Introduction}

Over the last couple of years, states have spent vast amounts of resources on the development and implementation of counterterrorism measures, ranging from security measures to the adoption of special legislation and from media campaigns to CBRN-proof equipment for first responders. However, the question where it got us, is still left unanswered. The problem is not that the state's counterterrorism efforts went unnoticed: there has been plenty of debate on especially the legal and ethical side of the matter. However, there is still no framework to assess whether the newly-introduced counterterrorism measures have yielded the desired results. This paper will therefore address the question of how effectiveness in counterterrorism should be measured. It will in the first section review some ways in which the effectiveness of counterterrorism strategies has been measured in counterterrorism research so far and will then wrap up this section by formulating the general difficulties that research into the effectiveness of counterterrorism measures suffers from. ${ }^{1}$ The second section will introduce an alternative approach. Rather than identifying metric measures of success for a counterterrorism policy as a whole and looking for combinations of measures whose introduction is followed by desirable scores, e.g. lower numbers of terrorist attacks, this approach argues in favour of breaking up success in counterterrorism into several 'success factors'. Briefly, success factors are activities for which it can be argued that they are helpful in the fight against terrorism and together constitute success in counterterrorism. Examples of success factors include restraint (the state should be very careful not to lash out and further antagonise the population), coordination (all players involved in counterterrorism should take into account the activities all other players when executing their own) and international cooperation (as planning or preparation of terrorist attacks may take place abroad, the relevant foreign countries need to be involved in the fight against terrorism). Using the example of a social reintegration program for convicted terrorists, it will be argued in the remainder of the second section that for all these success factors separately, it should be made explicit along which causal chain they are supposed to lead to success and how success should be measured.

\footnotetext{
${ }^{1}$ Perhaps surprisingly, there is little research that examines the effectiveness of counterterrorism measures. See C. Lum, L. W. Kennedy, and A. Sherley, "Are counter-terrorism strategies effective? The results of the Campbell Systematic Review on counterterrorism evaluation research," Journal of Experimental Criminology 2, no. 4 (2006): 489-516.
} 


\section{Measures of effectiveness}

\subsection{Direct consequences of terrorist attacks}

When assessing the effectiveness of counterterrorism strategies, it is tempting to look at statistics that can be derived from terrorist attacks. First, they provide hard data. This has the advantage that increases and decreases can be clearly established. Also, the numbers can be counted, compared and visualised in bar charts, which makes them seem like appealing and feasible indicators of success. Also, they seem to go to the heart of what terrorism is about. As the ultimate ambition of all counterterrorism practitioners is an end to terrorist attacks and casualties as a result of terrorist attacks, it makes intuitive sense to look at indicators like the numbers of terrorist attacks and the numbers of victims. However, there are severe drawbacks to this way of working. This section will discuss some measurements of effectiveness that used statistics derived from terrorist attacks.

\subsubsection{Numbers of terrorist attacks}

A widely-used indicator of success is the number of terrorist attacks. For example, Gary LaFree examined the effect of some interventions by the British state in Northern Ireland by looking at the numbers of terrorist attacks that took place after the measures had been implemented. ${ }^{2}$ Similarly, Pestana Barros tried to establish the effects of the opening up by the Spanish state of political channels for the ETA. He does so by comparing the numbers of attacks in periods in which the more conciliatory PP was in power to those in periods in which the more intransigent PSOE was in power. ${ }^{3} \mathrm{~A}$ third example is Hillel Frisch, who shows that the intensity of Palestinian violence decreases in periods when Israel uses massive force and offers no concessions. ${ }^{4}$

Although terrorists need a certain level of violence to maintain their credibility, there are good reasons to be critical of the use of numbers of terrorist attacks as indicators of success of counterterrorism measures. First, it is not clear what increases and decreases say about the

\footnotetext{
2 G. LaFree, Efficacy of counterterrorism approaches: examining Northern Ireland, START Research Brief, 2006, http://www.start.umd.edu/start/publications/research_briefs/20061017_lafree.pdf.

${ }^{3}$ C.P. Barros, "An intervention analysis of terrorism: the Spanish ETA case," Defence and Peace Economics 14, no. 6 (2003): 401412.

${ }^{4} \mathrm{H}$. Frisch, "Motivation or capabilities? Israeli counterterrorism against Palestinian suicide bombings and violence," Journal of Strategic Studies 29, no. 5 (2006): 866-867.
} 
state of the terrorist organisation committing the attacks. It is possible that a group in decline initiates a wave of terrorist attacks to send a message, both to its own members and to the population at large, that it is not finished yet. In this case, an increase in the numbers of attacks is certainly not a sign that a counterterrorism strategy is not working. An increase can also be the result of radicalisation of a movement in leadership transition, when the new leaders are vesting their authority by organising spectacular or large numbers of attacks.

A second problem with using numbers of attacks as indicators of success or effectiveness is that they do not say much about the impact of a terrorist campaign. Not all terrorist attacks are similar, and one would expect the impact of a large-scale attack, like $9 / 11$, one that requires much preparation, resources and operational capabilities, to be bigger than the impact of a simple arson. Going purely by numbers of attacks means that these differences will be ignored. This can be especially confusing if terrorist organisations decide to lower the frequency of their attacks to save resources for bigger, more advanced attacks. ${ }^{5}$ To complicate matters further, the numbers of terrorist attacks do not necessarily correlate with impact favourable for a terrorist organisation. Research has shown that the psychological impact of the IRA bombings was limited in parts of the United Kingdom that were often struck. ${ }^{6}$ Also, bombing campaigns can turn against the terrorists. There are already signs that al Qaeda is losing popular support in the Middle East because of the bloody attacks it commits. ${ }^{7}$ An increase in the number of terrorist attacks may be harmful to the cause of the terrorist organisation.

Finally, as the impact of a single attack can be huge, terrorist organisations do not need to commit as many attacks as possible. The assassination of a head of government of a cabinet member is a single attack, yet sends a very powerful message about a terrorist organisation's ability to disrupt a country's political process. A few small attacks can yield a terrorist organisation much more success than a series of bigger ones.

\footnotetext{
${ }^{5}$ D. Byman, "Scoring the war on terror," The National Interest 72 (2003): 81.

${ }^{6}$ A. Silke, "The psychological impact of terrorism: lessons from the UK experience," in Meeting the challenges of global terrorism: prevention, control, and recovery (Lanham: Lexington Books, 2003), 189-202.

7 P. Bergen and P. Cruickshank, "The unraveling: the jihadist revolt against Bin Laden," The New Republic, 2008, http://www.tnr.com/politics/story.html?id=702bf6d5-a37a-4e3e-a491-fd72bf6a9da1; "Al-Qaeda: the cracks begin to show," Times Online, http://www.timesonline.co.uk/tol/news/world/middle_east/article4087373.ece.
} 
A well-known body of research that examines the effects of counterterrorism on the basis of numbers of attacks, concerns target hardening measures to prevent airplane hijackings. ${ }^{8}$ This research shows that target hardening measures do indeed reduce the numbers of attacks on the newly hardened targets. However, Walter Enders and Todd Sandler themselves provide insights that would keep one from interpreting these measures too easily as successful. Again using numbers of terrorist incidents, they have demonstrated the substitution effect: the hardening of one kind of target leads to increases in the numbers of attacks on other targets. ${ }^{9}$ These findings suggest that defensive measures have a way of moving the problem somewhere else rather than solving it.

It is clear that the use of numbers of terrorist attacks as indicators of success comes with severe difficulties. Some of these may be fixed by looking at numbers of casualties.

\subsubsection{Numbers of victims}

A way around the argument that terrorist attacks are no equal units like dollars or inches, could be the inclusion of the number of casualties in the analysis. Yonah Alexander, editor of two volumes of comparative counterterrorism studies, and Nadav Morag included numbers of casualties as a criterion that counterterrorist campaigns should be judged by. ${ }^{10}$

Many of the arguments that can be made against using numbers of terrorist attacks can also be made against the use of numbers of casualties. Increases can be the result from radicalisation brought about by declining power or the eagerness of new leaders, populations can learn to accept victims of terrorist attacks as a fact of life and can even turn against terrorists for causing too many casualties. Regarding this latter point, it is interesting to note that some terrorist attacks, especially when there are children among the victims, can be operational successes but political disasters for terrorist organisations. The population will be outraged over the deaths over innocent victims and withdraw their support to the terrorists. An

\footnotetext{
${ }^{8}$ W. M. Landes, "An economic study of US aircraft hijacking, 1961-1976," Journal of Law and Economics 21 (1978): 1-31; J. Cauley and E. I. Im, "Intervention policy analysis of skyjackings and other terrorist incidents," The American Economic Review 78, no. 2 (1988): 27-31; W. Enders, T. Sandier, and J. Cauley, "UN conventions, technology and retaliation in the fight against terrorism: An econometric evaluation," Terrorism and Political Violence 2, no. 1 (1990): 83-105.

${ }^{9}$ W. Enders and T. Sandier, "The effectiveness of antiterrorism policies: a vector-autoregression-intervention analysis," American Political Science Review 78, no. 4 (1993): 829-844.

${ }^{10}$ Y. Alexander, "Introduction," in Combating terrorism: strategies of ten countries (Ann Arbor: University of Michigan Press, 2002), 1-23; N. Morag, "Measuring success in coping with terrorism: the Israeli case," Studies in Conflict and Terrorism 28, no. 4 (2005): $210-211$.
} 
argument that can be made specifically against the use of numbers of victims is that an increase in the number of casualties can be the result of a substitution effect from hardened to softer targets. If a terrorist organisation finds itself unable to strike at hard targets, it may choose to direct its attacks at targets that are easier to hit. ${ }^{11}$ Schools and market squares may then have to bear the brunt of the terrorist attacks, which will lead to higher numbers of casualties but should not be interpreted as a sign that the terrorist organisation is getting stronger. In this case, an increase in the numbers of victims can even be read as a sign of weakness of the terrorist organisation. Like numbers of attacks, numbers of victims have by themselves no unambiguous meaning.

\subsubsection{Material damage}

A final metric indicator of success in counterterrorism, although not one that is used very often, is material damage. ${ }^{12}$ This indicator suffers from largely the same problems as the previous two. It is not necessary to repeat the arguments from the previous paragraphs, so let it suffice to say that more material damage can make the population turn against the terrorists, can be the result of radicalization processes that are not related to any counterterrorism measures and can reflect a shift to easier targets on the part of the terrorist organization.

\subsection{Indirect indicators}

Instead of focusing on data about the direct manifestations of terrorism, some authors have looked at indirect indicators, i.e. fluctuations in indicators of the general functioning of a society that are thought to be influenced by terrorist attacks. For example, it has been argued that domestic and international support for the government executing the counterterrorism policy could serve as an indicator of the success of that policy. Although the support of the population is crucial for the success of a counterterrorism strategy, using it as an indicator of success is difficult, as it may result from other policies than a counterterrorism policy. Regarding domestic support, it may even be the case that a generous welfare policy may provide the government with the support needed to implement a counterterrorism policy that would otherwise not have been accepted. International support may well be generated by

\footnotetext{
${ }^{11}$ M. A. Sheehan, Crush the cell: how to defeat terror without terrorizing ourselves (New York: The Crown Publishing Group, 2007), 28-29 and L.E. Dutter and O. Seliktar, "To martyr or not to martyr: jihad is the question, what policy is the answer?", Studies in Conflict and Terrorism 30 (2007): 440.

12 Alexander, "Introduction."
} 
skilful diplomacy rather than by the counterterrorism policy itself. This is certainly not to question the importance of domestic and international support in counterterrorism. Quite the contrary, it is a sine qua non of success in both terrorism and counterterrorism, but it depends on so many other factors that it does not necessarily tell us much about the counterterrorism policy that was implemented. For example, a terrorist attack may convince a population about the need of certain controversial counterterrorism measures. Using support for the government as an indicator of effectiveness would give the impression that the counterterrorism policy was less effective on the day before the attack than on the day after, which is not a conclusion that most of us would be willing to accept.

Another option is to establish the effectiveness of a counterterrorism policy by looking at the functioning of the economy. This has been done by looking at the growth of the GDP and the fluctuations of the stock market. ${ }^{13}$ The assumption is here that, when the economy is thriving, the terrorists have not managed to severely disrupt the functioning of the country. The difficulties are obvious. First, fluctuations in the economy can be the result of many factors, most of which have nothing to with terrorism. Second, and this partly follows from the first point, terrorist attacks tend to have little impact on the economy. ${ }^{14}$ Even the $9 / 11$ attacks, which took place at the heart of the American economy, were too small and too localized to have serious consequences for an economy as vast and diversified as the American. ${ }^{15}$ The limited effect on the economy of these attacks, which have had vast effects in other spheres, begs the question whether the economy is sensitive to terrorist attacks at all and suggests that the economy is not the right place to look for the effectiveness of counterterrorism measures.

\subsection{Government action}

\subsubsection{Numbers of arrests}

This indicator is best known for its use by the US Government, which, for example, claimed in 2006 that the arrests of high level al Qaeda cadres showed that the US was making progress in the fight against terrorism. The capture of al Qaeda cadres, especially in Afghanistan in the

\footnotetext{
${ }^{13}$ Morag, "Measuring success in coping with terrorism: the Israeli case"; A. Zussman and N. Zussman, "Assassinations: evaluating the effectiveness of an Israeli counterterrorism policy using stock market data," Journal of Economic Perspectives 20, no. 2 (2006): 193-206.

${ }^{14}$ T. Sandler, D. G. Arce, and W. Enders, Terrorism: Copenhagen Consensus 2008 Challenge Paper (Copenhagen: Copenhagen Consensus Center, 2008), 18-19.

${ }^{15} \mathrm{G}$. Makinen, The economic effects of 9/11: a retrospective assessment, Report for Congress (Congressional Research Service, 2002), 18-19.
} 
wake of the overthrow of the Taliban, was hailed as a step towards paralysing the al Qaeda network. ${ }^{16}$ Of course, the arrest of any criminal is to some extent always a success for a state, as it is a way of asserting its ability to enforce its rules. Having said that, one should be careful not to read too much into it.

For one thing, at least in the case of al Qaeda, terrorists can easily be replaced. It has long been recognised that when al Qaeda cadres are arrested, or eliminated for that matter, new recruits are eager to take their places. ${ }^{17}$ The more popular the movement, the bigger the pool of possible successors to arrested terrorists. Second, arrests, especially in large numbers, may have consequences that do certainly do not qualify as success for the state. In some cases, the arrests themselves may draw people who were previously only sympathisers into the terrorist organisation. Infuriation over the treatment of friends and relatives by the state, including waves of arrests, has proven to be a powerful motive for joining a terrorist organisation, for example in the case of the IRA. ${ }^{18}$ Another way in which arrests can indirectly and inadvertently exacerbate the situation concerns the power vacuum that results from arrests of leading cadres. The new leaders may want to underline the credibility of their claims to dominance by advocating spectacular actions, which can thus lead to radicalisation of the organisation. The third difficulty in using numbers of arrests is that they may very well be indicators of things other than success. For example, it may tell us more about the performance of the police forces making the arrests. The numbers of arrests may have gone up as a result of a re-orientation on the part of the police, which may have decided to put more pressure on the terrorists. Although an increase in the numbers of arrests can then be a goal in itself, it does not mean that that a policy has been successful. Another possibility is that the number of arrests has gone up as a result of an increase in terrorist activity. Assuming that the same percentage of active terrorists will under similar circumstances get arrested, an increase in the numbers of arrests may indicate a reinvigoration of a terrorist campaign. This is not to say that changes in the numbers of arrests should be interpreted along these lines, but that they in themselves provide no basis to draw conclusions about success or effectiveness.

\footnotetext{
${ }^{16}$ US Government, "9/11 five years later: successes and challenges," 2006, 4 and 7.

17 B.M. Jenkins, Countering al Qaeda: an appreciation of the situation and suggestions for strategy (Santa Monica: RAND Corporation, 2002), 10.

${ }^{18}$ W. E. Cralley, A. J. Garfield, and C. Echeverria, Understanding terrorism: lessons of the past - indicators for the future, IDA Paper (Alexandria: Institute for Defense Analyses, 2004), III-5; B. Riedel, The search for al Qaeda: its leadership, ideology, and future (Washington, DC: Brookings Institution Press, 2008), 16.
} 
The only situation in which numbers of arrests could be used as an indicator of success is a campaign against a declining organisation with a known size and little to no outside support. Only then, when one can be certain that arrested members will not be replaced and that arrests will not generate support for the terrorists, can making arrests be seen as chipping away at the organisation.

\subsection{General difficulties with measures of effectiveness}

Drawing on the objections that can be made against the abovementioned indicators of success, we can now identify three major factors that affect the feasibility of the indicators of success that have been used so far in counterterrorism research. This section will also discuss substitution effects, which throw doubt on the feasibility of the measures of success, not because they question the validity of the measures of effectiveness, but because they suggest that counterterrorism success may cause problems elsewhere.

\subsubsection{Difficulties with the meaning of indicators}

First, the problem with many of the indicators discussed above is that it is not clear whether they can be interpreted as a success. There are a lot of possible causes for increases in numbers of terrorist attacks, as there are a lot of reasons why the numbers of arrested terrorists might go up. Before we know more about the drivers behind the dynamics in these indicators, using them as indicators of success is not a viable option.

Second, even if it is clear that a change in the indicators can be interpreted as a success, there is still the attribution problem. We have seen above that it is not clear for all indicators, especially the ones referring to the economy, that changes are driven by counterterrorism. $\mathrm{A}$ factor that further complicates matters, is that there are often quite a few counterterrorism measures in place at the same time. Even if an appropriate measure of effectiveness would be found, it would still be unclear which instrument or measure or which combination of instruments or measures had brought about the desired effect. Also, it may well be that the beneficial effects of one instrument are drowned out by the negative effects of others. The interpretation problem and the attribution problem are strongly related: gaining clarity about what caused a change in an indicator (solving the attribution problem) will also shed light on whether that change is desirable or not (solving the problems with the interpretation). 
The third general difficulty with the interpretation of indicators of counterterrorism success is the problem of the difference between operational and strategic success. This argument is especially pressing for the indicators that draw on terrorist attacks. A mistake often made, by scholars and practitioners alike, is to apply the logic of regular warfare to counterterrorism. ${ }^{19}$ The use of numbers of arrests, victims or attacks to measure success or effectiveness rests on the assumption that the outcome of the confrontation is decided by operational capabilities. If a terrorist organization is becoming more active or more violent, it is closer to defeating the state and thus to gaining success. In the same vein, if the state breaks up a terrorist cell and thus reduces the operational capabilities of the terrorist organization, the state is perceived to be winning. This line of reasoning mistakenly applies the logic of state-to-state - warfare to a conflict between a state and a terrorist organization. In the former case, where the goal on both sides is to inflict a decisive defeat on the enemy, it is perfectly legitimate to identify operational success (e.g. winning a battle) with strategic success (decisively defeating the enemy). The problem is that the confrontation between a state and a terrorist organisation is a political, not a military confrontation. A certain degree of operational success does not necessarily imply a similar degree of political success. ${ }^{20}$ For example, we have seen that terrorist attacks can backfire against terrorist organizations, especially when there are children among the victims. Another demonstration of the oblique relationship between operational and strategic success in terrorism and counterterrorism is the argument made by Brian Michael Jenkins, who claims that al Qaeda does not necessarily need nuclear capabilities to be a nuclear power. It instils fear for nuclear terrorist attacks without ever having displayed the capabilities to acquire and employ nuclear weapons. ${ }^{21}$ This means that in terrorism, political or strategic success can be achieved in the absence of operational success, an observation that goes to underscore the main point that should be made here: operational success does not automatically translate into political success, and politics is what ultimately decides the outcome of the confrontation. There are several ways in which terrorists can try to get their way. For example, terrorists can commit terrorist attacks to raise the costs of the continuation of certain government policies, they can undermine confidence in the state by showing that its violence against the population at large can go unpunished and they can commit their attacks to provoke a violent reaction from the state that will make the population against the state. ${ }^{22}$ None of these strategies

\footnotetext{
19 See for example A. Bolivàr, "Peru," in Combating Terrorism: Strategies of Ten Countries (Ann Arbor: University of Michigan Press, 2002), 95.

${ }^{20}$ E. F. Mickolus, "Comment--Terrorists, governments, and numbers: counting things versus things that count," Journal of Conflict Resolution 31, no. 1 (1987): 55-56.

${ }^{21}$ B.M. Jenkins, Will terrorists go nuclear? (New York: Prometheus Books, 2008), 241-276.

${ }^{2}$ A. H. Kydd and B. F. Walter, "The strategies of terrorism," International Security 31, no. 1 (2006): 49-80.
} 
suggest a necessary relation between operational and political success. Terrorism is a way of sending a message, and its success therefore depends on the way that message is perceived. Will the government feel forced to cut its losses and cease following a certain policy? Will the population lose confidence in the state as a result of a series of terrorist attacks? Will the state indeed react violently to retaliate for terrorist attacks? Terrorists can only try to influence minds, they do not control them. The reaction to a certain level or kind of terrorist violence is not always easy to predict as it does not automatically follow from the terrorist violence alone. Instead of wavering in the face of terrorist violence, a government may become more determined to stay put. Instead of losing confidence in the state, civilians may rally around it because they see it as their only option for protection against terrorist attacks. Instead of lashing out in reaction to terrorist attacks, governments may hold back to avoid coming across as the repressive monster the terrorists make it out to be. Although data derived from terrorist violence can be very useful for analyses regarding changes in the modus operandi of terrorist organisations, there are too many caveats regarding their usefulness as indicators of success to use them to evaluate the effectiveness of counterterrorism strategies.

\subsubsection{Substitution effects}

Two other difficulties that should be raised, concern the viability of the idea of success in counterterrorism in the first place, regardless of the way in which it is being measured. Even assuming that one of the indicators above would help to identify successes in counterterrorism, this notion of success itself might be too narrow. Success in one place may lead to setbacks in other places and success against one form of violence may lead to an increase in others.

First, there is the geographical substitution effect. Measuring or describing the effectiveness of a counterterrorism policy or a counterterrorism measure often happens on a state by state basis. Counterterrorism policies are national policies, or at least policies that are implemented by a government with control over a certain territory. Consequently, the effects of that policy are understood as effects that manifest themselves on that particular territory. This way of working ignores the geographical substitution effect. Eradication of a terrorist movement in one country may divert the people and the resources to movements in other countries. A clear example, although some may argue that it does not concern a terrorist organization, is the spread of Stop Huntingdon Animal Cruelty (SHAC) over Europe. In 2004, the British 
government adopted a set of measures that made it impossible for SHAC, an extremist animal rights movement, to function in the UK. In the years since, the members of SHAC have spread over Europe and have contributed to the radicalization of the European extremist animal rights movement. ${ }^{23}$ The success of the British legislation against animal rights extremism thus came at the expense of more animal rights extremism elsewhere in Europe. Similarly, experts have noticed that ever since it has become clear that al Qaeda jihadists were losing ground in Iraq, the focus of jihadist activity has shifted to Afghanistan. ${ }^{24}$ Second, there is the functional substitution effect, which means that terrorism does not really disappear, but rather turns into different forms of aggression. A narrow view of success in counterterrorism, for example in cases where the effectiveness of counterterrorism policies is measured on the basis of statistics on terrorist attacks, pays no heed to the possibility that the substitution effect in counterterrorism can also manifest itself as a shift from terrorism to other ways of expressing discontent, for example vandalism. ${ }^{25}$ These two substitution effects go to show that what is perceived as success in counterterrorism can also be a mere change or displacement of the problem. It is interesting to note that terrorism itself can in some cases be perceived as a functional substitution effect of other forms of political violence. For example, Palestinian resistance resorted to terrorism after the Six Day War because it lacked the resources and room for manoeuvre to continue its guerrilla campaign. ${ }^{26}$ Thus, what goes for the disappearance of terrorism also goes for the disappearance of other forms of political violence: a focus only on that problem may lead to misinterpretations of measures of success.

\section{Success factors in counterterrorism}

The discussion above is meant to make clear that the ways in which the success of counterterrorism has been measured so far are fraught with difficulties that undermine the credibility of exercises that rely on one of the indicators of success mentioned above. The remainder of this contribution will argue a different approach. The core idea behind this alternative approach to measuring the effectiveness of counterterrorism is that success should be broken down in separate components, each with their own indicators of success. Instead of

\footnotetext{
${ }^{23}$ AIVD, Animal rights activism in the Netherlands: springboard for Europe (The Hague: Ministerie van Binnenlandse Zaken, 2007), $12-13$.

24 "Afghanistan's 'pristine jihad' draws in outsiders trained in Pakistan," Times Online, 2008, http://www.timesonline.co.uk/tol/news/world/middle_east/article4368820.ece.

${ }_{25}$ A.R. Brotóns and C. Espósito, "Spain," in Combating terrorism: strategies of ten countries (Ann Arbor, 2002$), 176-177$.

${ }^{26}$ B. O'Neil, "Towards a typology of political terrorism: the Palestinian resistance movement," Journal of International Affairs 32 , no. 1 (1978): 31 and 42.
} 
relying on indicators that represent the effectiveness of a counterterrorism policy as a whole, one should first think of what elements constitute a success in counterterrorism policy. For all these success factors, about which more will be said below, it needs to be explicitly formulated along which causal chain they lead to effectiveness.

The problem with the indicators discussed above is not that they are per se useless, but that it is not made clear how they constitute effectiveness. An explanation of the causal chain between cause (a counterterrorism measure) and effect (shifts in the scores of indicators / effectiveness) would help justify the choice for a certain indicator of effectiveness. However, such a program theory is difficult to formulate when the indicator is supposed to say something about something as multifaceted as a counterterrorism policy in its entirety. To credibly attribute shifts in the scores of indicators to counterterrorism measures, counterterrorism needs to be broken down in separate components, each with their own indicators of effectiveness. Breaking down counterterrorism in its separate components, it is easier to tell through which causal chain a measure or an element of a policy is supposed to lead to a desired result. After that measure has been introduced, the evaluation of its effectiveness would amount to examining whether the causal chain has played out in reality. An example may clarify this.

One could imagine that a social reintegration program for convicted terrorists has as its ultimate goal the undermining of the morale of a terrorist organisation, as a result of which it will fall apart. A successful social reintegration program would offer people in terrorist organisations an opportunity to leave, thus sowing mistrust within the organisation, where the members would start to question the loyalty of other members. Since it is unlikely that a social reintegration program by itself would achieve this result, one might add an efficient law enforcement apparatus, which heightens the risk of capture and diminishes the chance of success, as a precondition for the social reintegration program to be successful. When the pressure of law enforcement agencies is high, members of the terrorist organisation may be more susceptible to alternatives to membership of the terrorist organisation. The causal chain then becomes: 


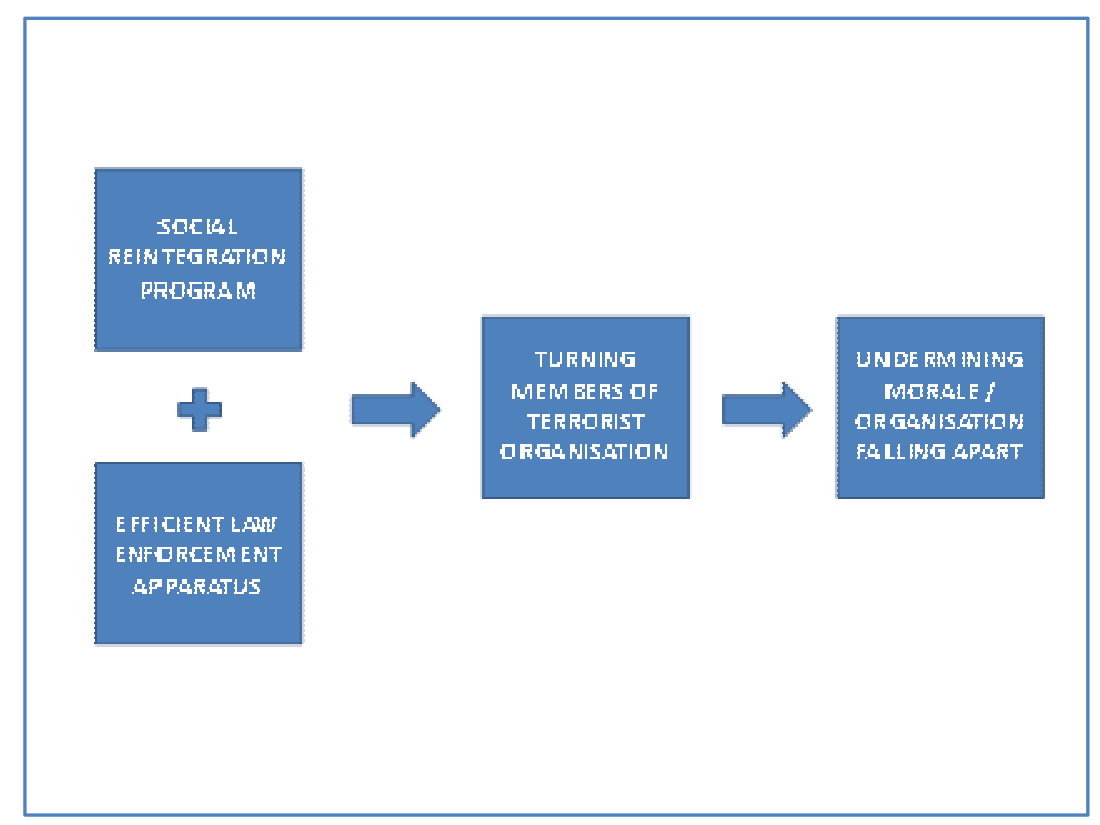

Figure 1: a program theory about social reintegration programs

A state implementing a social reintegration program for convicted terrorists could reason that the combination of pressure and more attractive alternatives to terrorism will make the reintegration program a success: it succeeds in releasing convicted terrorists back into society without them falling back into the terrorist organisation. Once the program has been running for some time, the secret services would have to provide the intelligence to tell whether the reasoning held in practice. Is the morale of the organisation being undermined by the program? Are the members of the terrorist organisation indeed eager to leave? Is the mutual mistrust growing? These are all questions that provide input for the formulation of indicators of success. In this particular case, one could think of using the number of splits or decreasing intensity of contact between members of the organisation as indicators of success. The line of reasoning used in this example is very simple, but goes well to illustrate how each separate component of a counterterrorism policy could be evaluated separately to avoid some of the pitfalls discussed in the previous section. By carefully monitoring it can be ascertained whether or not the program theory, the assumption about how a policy is supposed to lead to effectiveness, actually holds. The attribution problem and the problem of the meaning of indicators are then partially solved: we have not only a correlation between the introduction of a policy and a shift in an indicator, but can also show how the two hang together. 
Going over the counterterrorism literature, it is certainly possible to find elements that a counterterrorism policy should contain. Drawing on that literature, the following success factors, activities for which it can be argued that they are helpful in the fight against terrorism, can be identified:

Restraint in the use of force. States should be careful not to antagonise the population by the excessive used of force. It may lead to escalation of violence and may gain the terrorist organisation support. ${ }^{27}$

International cooperation. As many terrorist attacks are planned of financed in other countries than where they are executed, states need the help of other states to deny terrorist organisations the resources and space to plan their attacks. ${ }^{28}$

Coordination and strategy. To avoid interagency infighting and insufficient intelligence dissemination, all players involved in counterterrorism should be committed to a common strategy, he implementation of which is overseen by a coordinator with the power and responsibilities to lead. ${ }^{29}$

Offering non-violent options. To draw organisations away from terrorism, the state should, by negotiation or the opening up of regular, non-violent political channels, make clear that nonviolent ways of achieving political goals have more chance of success. ${ }^{30}$

Gathering intelligence. It is crucial that the state acquires the intelligence to predict the terrorists' next move, foil their plots and, as we have seen, monitor the effect of countermeasures. ${ }^{31}$

\footnotetext{
${ }^{27}$ A. K. Cronin, "Rethinking sovereignty: American strategy in the age of terrorism," Survival 44, no. 2 (2002): 127; A. Faruqui, "Is the USA fighting terrorism with the wrong weapons?," Security Dialogue 34, no. 1 (2003): 122; N. Dower, "Against war as a response to terrorism," Philosophy \& Geography 5, no. 1 (2002): 29-30; M. Howard, "What's in a name? How to fight terrorism," Foreign Affairs 81, no. 1 (2002): 10-11.

${ }^{28}$ See for example P. R. Pillar, "Counterterrorism after Al Qaeda," The Washington Quarterly 27, no. 3 (2004): 106-107; C. J. Oudraat, "Combating terrorism," The Washington Quarterly 26, no. 4 (2003): 163-164.

${ }^{29}$ See for example P. R. Pillar, "Intelligence," in Attacking terrorism: elements of a grand strategy , 2004, 117-121; B. Hoffman and

J. Morrison-Taw, A strategic framework for countering terrorism and insurgency (Santa Monica: RAND Corporation, 1992), 6-30

${ }^{30}$ See for example J. L. Windsor, "Promoting democratization can combat terrorism," The Washington Quarterly 26, no. 3 (2003):

47-48.

${ }^{31}$ B. Ganor, The counter-terrorism puzzle: a guide for decision makers (New Jersey: Transaction Publishers, 2005$), 47$.
} 
Perform basic state tasks. Terrorism is a way of undermining state authority, so it is very important that the state remains in control, especially when it comes to providing security to its citizens. An efficient law enforcement mechanism that manages to capture and try perpetrators of terrorist attacks goes a long way in showing the futility of terrorism. ${ }^{32}$

Address root causes. To win the support of the terrorists' constituency, the state should eliminate the grievances that bring people to support terrorism. This could concern cultural or social discrimination, economic inequality and more specific political demands, such as ending an occupation.

Long-term commitment. History has shown that, as terrorist campaigns progress, the population can grow weary of terrorist violence and will withdraw their support to the terrorists, which happened for example in Northern Ireland, Spain and India. ${ }^{33}$ This means that the state has to be willing to commit itself to a position vis-à-vis the terrorist organisation for the long haul.

Counter-narrative. To undermine the ideological support of the terrorist organisation, the state must have a message to persuade the terrorists' constituency and to a lesser extent the terrorists themselves of its benevolence and dispel the accusations about repression. ${ }^{34}$

Offer alternatives to membership of terrorist organisations. This is the example we used earlier. States should make sure that members of terrorist organisations have the opportunity to step out of the terrorist organisation. Leaving the terrorist organisation should be made more attractive, for example by providing the means for a definitive return into society.

For all these success factors, separate evaluations should be set up. They are formulated on the strategic level, but it should be possible to specify what they success they should achieve, how that success should be measured, along which causal chain that success will come about

\footnotetext{
32 See for example William C. Banks, Mitchel B. Wallerstein, and Renée de Nevers, Combating terrorism: strategies and approaches (Washington, DC: CQ Press, 2007), 140-141.

${ }_{33}$ M. Crenshaw, "Thoughts on relating terrorism to historical contexts," in Terrorism in context (Pennsylvania: University of Pennsylvania Press, 1995), 18-19.

${ }^{34}$ See for example D. Omand, "Countering international terrorism: the use of strategy," Survival 47, no. 4 (2005): 109-110.
} 
and what instruments are supposed to bring it about. Figure 2 shows these steps, with the concrete example of the social reintegration program for illustration.

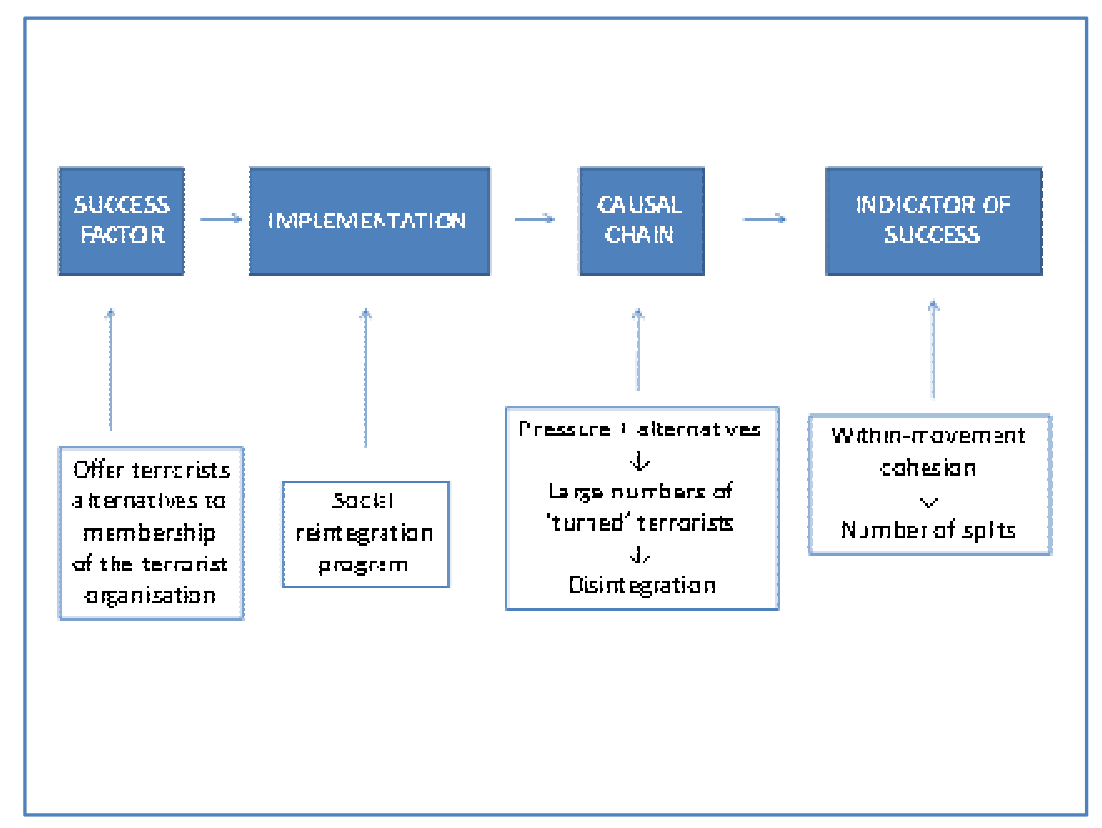

Figure 2: elements of the evaluation of success factors

\section{Conclusion}

This paper has tried to offer a solution for the problems that come with attempts to measure the effectiveness of counterterrorism. We should give up attempts to find indicators that tell us something about the effectiveness of a counterterrorism policy as a whole. Instead, we should start out from the assumption that counterterrorism is made up of many different elements, all with their own indicators of success. The success factors formulated above serve as an example of how counterterrorism could be broken down. But whichever way to break counterterrorism down is chosen, this differentiated approach calls for separate evaluations. Not only does this have the advantage of showing where a counterterrorism policy is doing well and where it is not, evaluations of success factors are easier to execute than evaluations of entire counterterrorism policies, because fewer factors need to be taken into account. This makes for more credible cause and effect relations that can later on be examined for evaluation. Has the cause and effect chain played out the way we initially thought it would? It is possible that some of the indicators we have discussed above can be useful, but then only if it 
can be made clear that it is the desirable result of a specific element of a counterterrorism policy. 